\title{
A FOTOGRAFIA E SEUS USOS NO CANDOMBLÉ DA BAHIA ${ }^{1}$
}

\author{
PHOTOGRAPHY AND ITS USES IN BAHIAN CANDOMBLÉ
}

Lisa Earl Castillo ${ }^{2}$

\begin{abstract}
Resumo: A fotografia nos terreiros é frequentemente entendida apenas como uma prática externamente imposta, o que teria dado origem às conhecidas restrições sobre a fotografia que se encontram em muitas casas. Este artigo examina os usos da fotografia no candomblé, mostrando que apesar de existirem receios reais, alguns gêneros específicos de imagens são valorizados nos terreiros desde o século XIX. As diversas atitudes sobre a fotografia e as práticas envolvendo elas são marcadas por uma epistemologia híbrida, influenciada tanto por valores africanos quanto pelo contexto social no qual o candomblé surgiu no Brasil.
\end{abstract}

Palavras-Chave: Fotografia, Religiões afro-brasileiras, Candomblé - Bahia, Antropologia visual.

\begin{abstract}
Many candomblé communities do not allow picture taking in the religious context. For this reason, photography is often viewed as a practice imposed by outsiders. This article examines the uses of photography in candomble and explores the attitudes surrounding them, showing that despite certain misgivings, there are also specific contexts in which photography has been valued since the nineteenth century. The differences in attitudes regarding the various uses of photography are marked by a hybrid epistemology influenced by African values as well as by the social context in which candomble arose in Brazil.
\end{abstract}

\footnotetext{
${ }^{1}$ Uma versão anterior deste texto foi publicada em inglês, sob o título "Icons of Memory: Photography and its Uses in Bahian Candomblé", no Stockholm Review of Latin American Studies, no. 4, março de 2009, pp. 11-23. A versão atual foi traduzida ao português por Mariângela Nogueira e revisada pela autora. Agradecimentos a Mattijs Van de Port por seus comentários à primeira versão deste texto.

2 Doutora em Letras pela Universidade Federal da Bahia (UFBA), atualmente bolsista de pós-doutorado da Fundação para o Amparo a Pesquisa do Estado de São Paulo (Fapesp), vinculada ao Centro para a História Social da Cultura (Cecult), Departamento de História, Universidade Estadual de Campinas (Unicamp). Endereço eletrônico: lisa.earl.castillo@gmail.com
} 
Keywords: Photography, Afro-Brazilian religions, Bahia, Visual anthropology, Candomblé.

Durante o século XIX, o surgimento de terreiros de candomblé na Bahia foi facilitado pelo crescimento, sobretudo na capital, de uma elite negra, constituída por africanos e africanas libertos abastados, com capital para investir em imóveis e outros bens. Esses libertos articulavam-se com seus seguidores através de extensas redes sociais que, além de girar em torno de instituições sociais africanas, também valiam-se de novas modalidades próprias do contexto do Brasil, como o compadrio e as confrarias católicas. Os fundadores dos terreiros mais antigos, como a Casa Branca, o Alaketu, o Gantois, o Bogum e a Roça do Ventura, faziam parte desse grupo privilegiado. Alguns desses sacerdotes e sacerdotisas fizeram viagens de retorno à África, assim como a outras partes do Brasil, levando produtos, participando em rituais e auxiliando na fundação de terreiros. Nas comunidades religiosas afro-brasileiras, a memória desses indivíduos e suas viagens é mantida viva e acalentada até hoje (VERGER, 1987, 1992; LIMA, 2003; MATORY, 2005; PARÉS, 2006). ${ }^{3}$

$\mathrm{Na}$ etnografia das religiões afro-brasileiras, o candomblé foi, durante muito tempo, abordado quase exclusivamente através da lente de sobrevivências africanas - ou seja, práticas e crenças trazidas da África que não sofreram alterações significativas no Brasil - um quadro analítico ainda hoje presente na literatura acadêmica. No entanto, a mobilidade dos sacerdotes oitocentistas, sua capacidade articuladora e sua astuta utilização de instituições e costumes que encontraram no Brasil, bem como sua evidente independência financeira, apontam para certa integração na modernidade de sua época, quando navios a vapor, estradas de ferro e telégrafos revolucionavam os transportes e a comunicação, e a fotografia transformava as artes visuais. Na década de 1840, quando os terreiros citados acima estavam se consolidando, fotógrafos itinerantes com daguerreótipos já viajavam de cidade em cidade pelo Brasil.

\footnotetext{
${ }^{3}$ No caso da Casa Branca, nova documentação histórica confirma muitos aspectos das tradições orais sobre as viagens de retorno à África. Cf. Castillo e Parés (2007) e Castillo (2012). Sobre a participação em irmandade católicas por comunidades de terreiro no século XIX, ver Castillo (2011). Para uma análise da trajetória de um importante babalaô no mesmo período, ver Domingos Sodré, um sacerdote africano: escravidão, liberdade e candomblé na Bahia do século XIX, de João José Reis (2008).
} 
Com impressão em metal, esta técnica fotográfica custava caro, mas em meados dos anos 1850, surgiram a impressão da imagem fotográfica em papel e as técnicas para a reprodução de imagens múltiplas a partir de uma única pose. Essas inovações reduziram o preço da fotografia e fizeram com que o emergente meio visual fosse acessível a um maior número de pessoas (KOSSOY, 2003).

Ainda assim, a fotografia permanecia basicamente um luxo das elites e a maioria das fotos que conhecemos hoje de africanos e seus descendentes no Brasil daquela época não são, em hipótese alguma, autorrepresentações. São imagens que visam a representação do exótico, captadas por um olhar objetificador, a maioria produzida por um pequeno grupo de fotógrafos, entre eles Christiano Junior, Alberto Henschel e Augusto Stahl. Algumas dessas imagens, de escravos com os pés descalços e escarificações faciais que encenam ofícios “típicos”, eram vendidas como lembranças turísticas. Há também os retratos tirados para enfeitar os álbuns da infância, com ioiôs e iaiás no colo de suas babás ou amas de leite vestindo traje europeu formal. Ainda outra categoria são as imagens produzidas para alimentar as fantasias eróticas de homens da classe senhorial, para quem o corpo da mulher negra era um objeto secreto de desejo: fotos de belas raparigas "crioulas" em vestidos sedutores com decotes profundos. Mas os registros visuais mais insidiosos são os que surgiram através do olhar antropométrico: fotos de homens e mulheres, completamente nus, cujos traços físicos eram medidos e catalogados como evidências para apoiar as teorias do racismo científico em voga (AZEVEDO E LISSOVSKY, 1988; SCHWARCZ, 1993; ERMAKOFF, 2004; LEITE, 2011; KOUTSOKOS, 2010; BALANTA, 2012). Significativamente, o que as pessoas fotografadas achavam dessas imagens não foi registrado. 


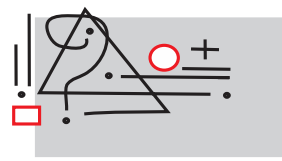

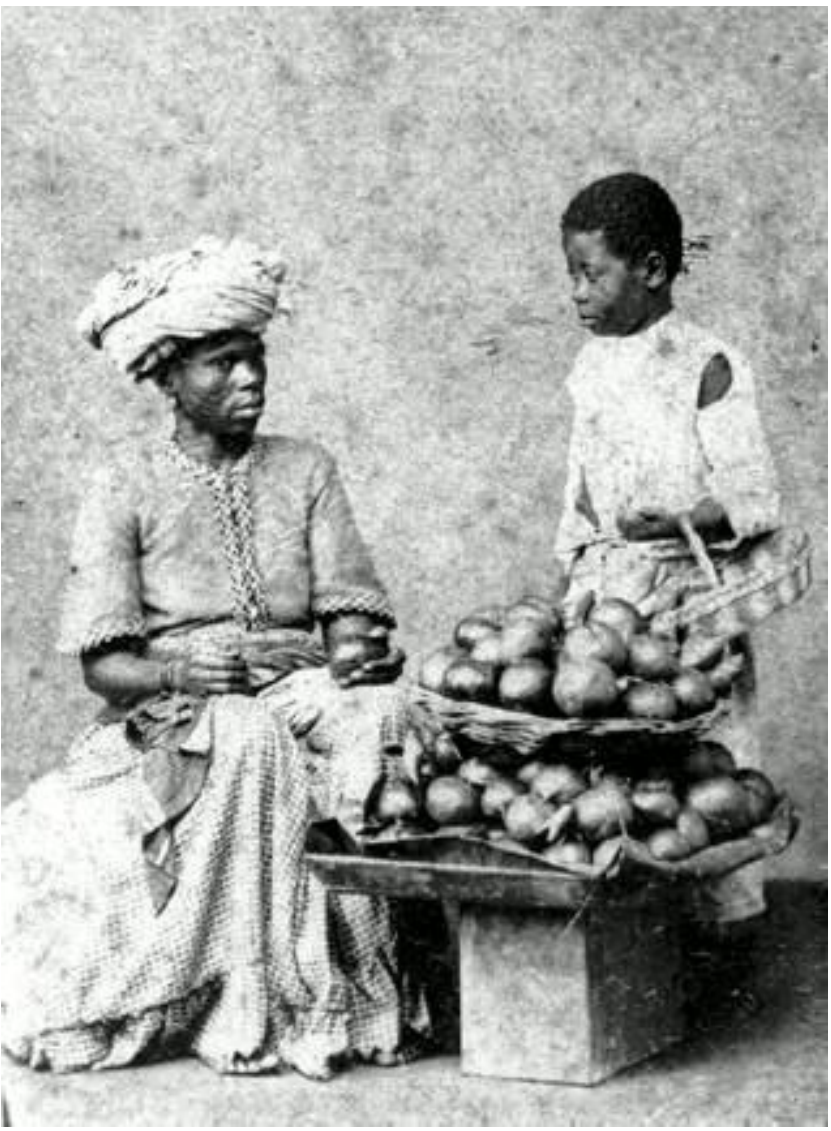

Figura 1: Ganhadeira nagô com criança. Christiano Jr., Rio de Janeiro, ca. 1865. Fonte: Arquivo Noronha Santos, Instituto do Patrimônio Histórico e Artístico Nacional, Rio de Janeiro.

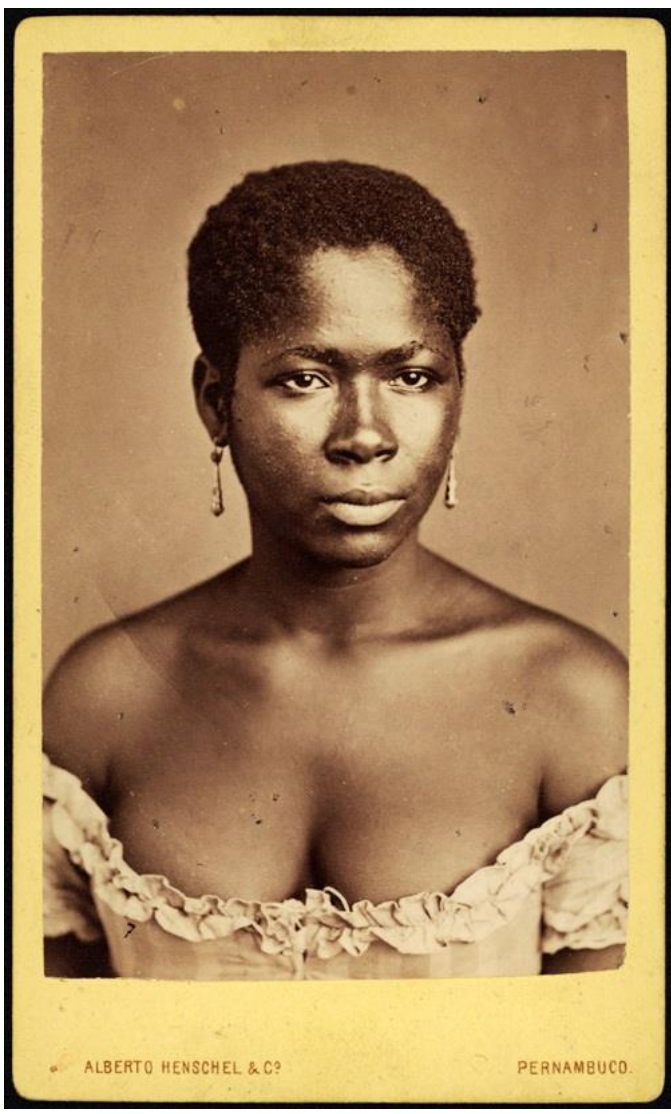

Figura 2: Mulher negra em Pernambuco. Alberto Henschel, ca. 1869. Usada com permissão do Leibniz-Institut für Länderkunde, Leipzig, Alemanha.

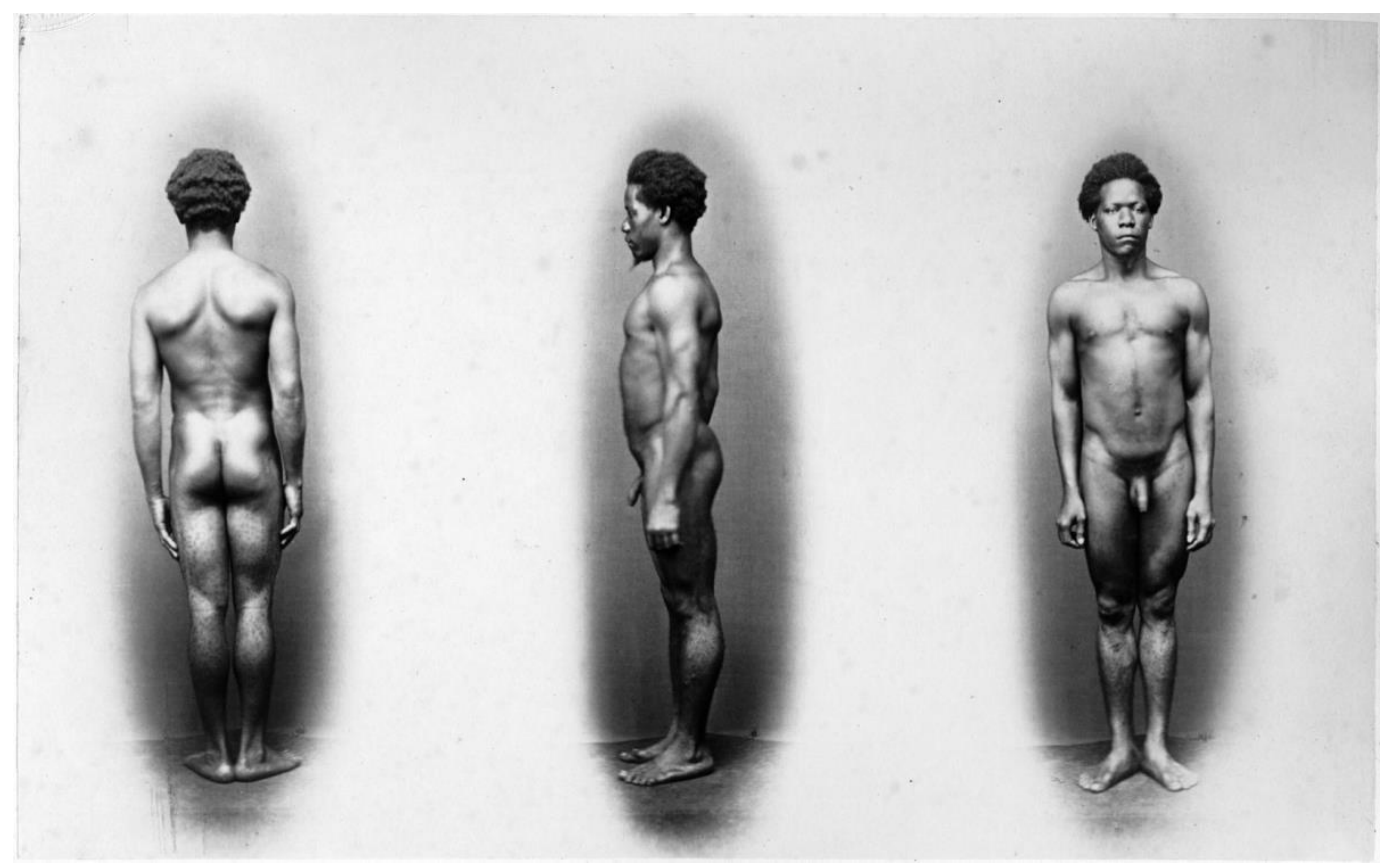

Figura 3: Exemplo da visão antropométrica, numa imagem de Augusto Stahl, ca. 1865. Usada com permissão do Peabody Museum of Archaeology and Ethnology da Harvard University. Identificação de imagem: 2004.1.436.1.156, arquivo digital no. 97480027. 
Pontos de Interrogação, v. 3, n. 2, jul./dez. 2013

Revista do Programa de Pós-Graduação em Crítica Cultural

Universidade do Estado da Bahia (UNEB), Campus II - Alagoinhas - BA

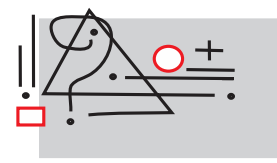

pontos de interrogaçãa

\section{A FOTOGRAFIA DO CANDOMBLÉ}

As imagens mencionadas acima começam a aparecer na década de 1860, mas em relação ao candomblé, o uso da fotografia ganhou visibilidade social no início do século XX, quando a perseguição às práticas religiosas afro-brasileiras intensificou-se e violentas batidas policiais se tornaram parte do cotidiano dos terreiros. ${ }^{4}$ Matérias de jornais, aplaudindo a destruição de santuários e a prisão de adeptos, eram ilustradas por fotografias que davam rostos aos nomes dos acusados e mostravam as "bugigangas" e os "apetrechos de fetiche" apreendidos.

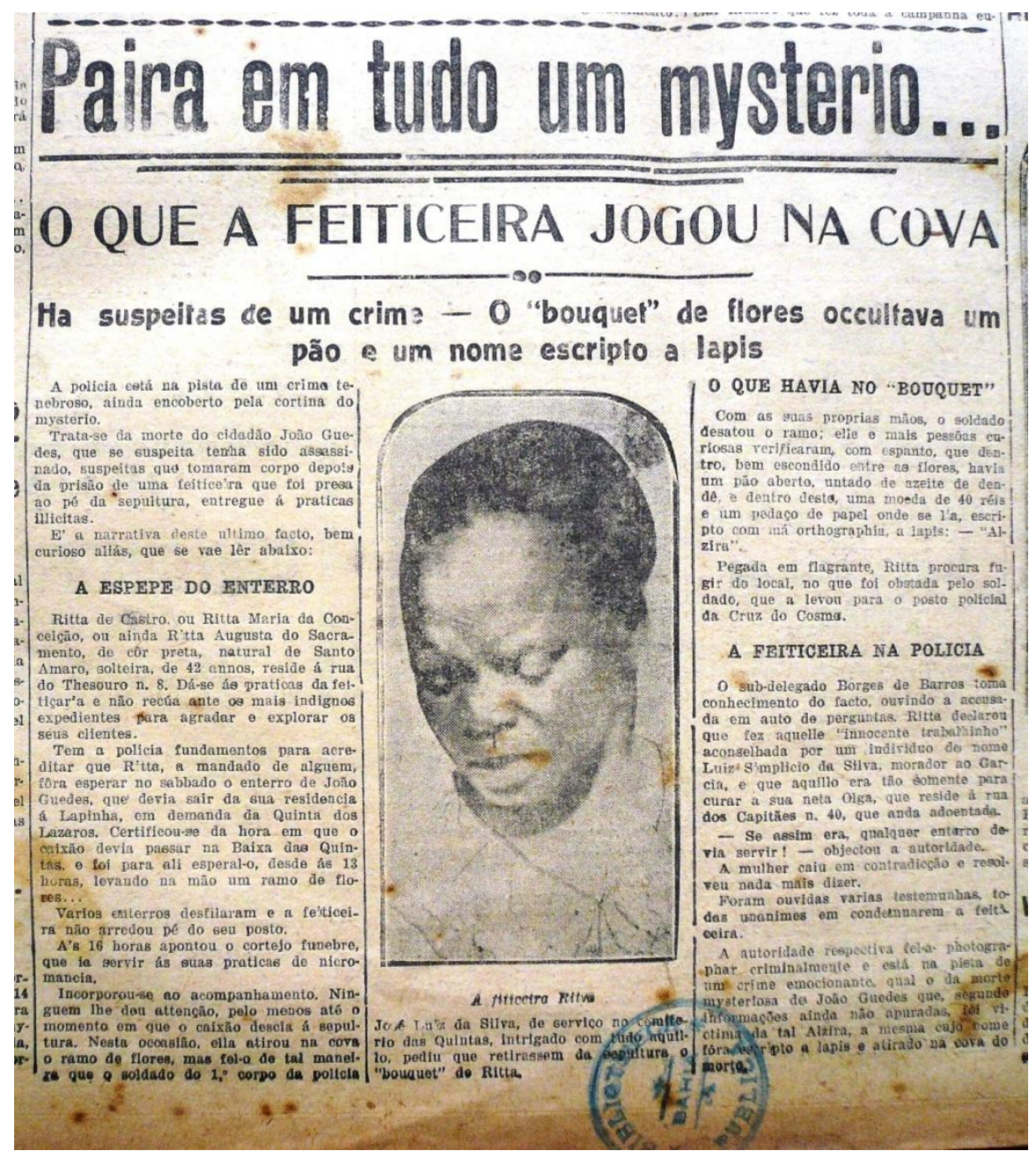

Figura 4: Matéria de jornal aplaudindo a prisão de uma mulher acusada de feitiçaria. A Tarde, Salvador, Bahia, 16 de outubro de 1923, p. 1.

\footnotetext{
${ }^{4}$ Sobre a perseguição sofrida pelos terreiros nessa época, ver Lühning (1995) e Braga (1995).
} 


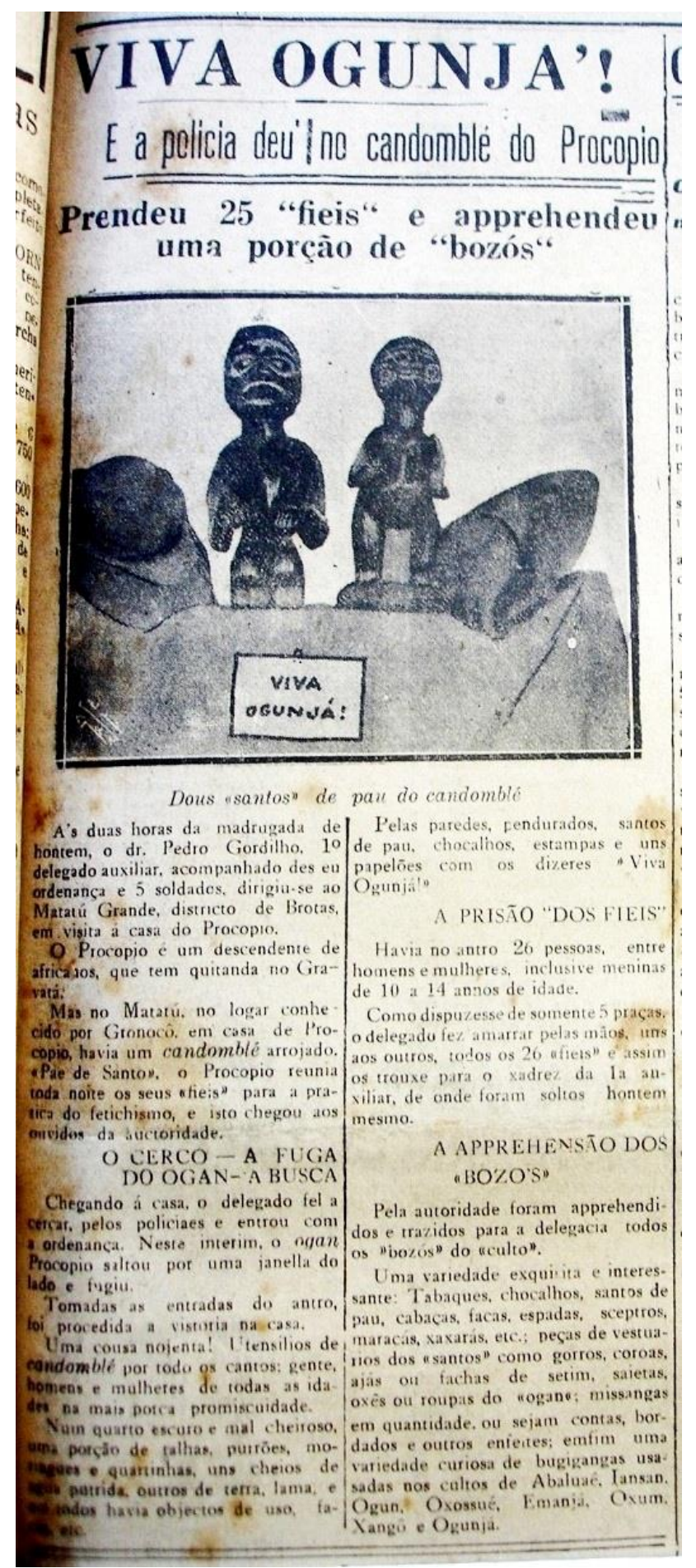

Figura 5: Matéria sobre a invasão policial no terreiro de Procópio Xavier de Souza, com foto de esculturas apreendidas como evidência de feitiçaria. O Imparcial, Salvador, Bahia, 20 de maio de 1920, p. 6. Liderado pelo delegado Pedro de Azevedo Gordilho, conhecido como Pedrito, o incidente é ainda notório na memória do povo de santo, Agradeço a Neuracy Moreira pela localização desta matéria. 
Foi nessa época, marcada pelo racismo científico e pela perseguição policial aos terreiros, que o estudo das religiões afro-brasileiras começou a tomar forma como campo acadêmico, a partir da obra de Nina Rodrigues que começava a ser publicada na última década do século XIX (RODRIGUES, 1896). A influência do racismo científico no seu trabalho tem sido muito comentada e não é nosso objetivo aqui. Mais importante para o nosso propósito é sua preocupação com a "pureza" africana, que durante gerações sucessivas de pesquisas sobre o candomblé continuou a influenciar outros estudiosos, como Edison Carneiro, Roger Bastide, Pierre Verger e Juana Elbein. ${ }^{5}$ Um ponto positivo dessa abordagem é que ela documentou vários aspectos da resiliência das religiões afro-brasileiras num contexto social extremamente hostil e opressivo. Mas, por outro lado, esse enfoque descartou elementos sugestivos da modernidade. A plasticidade dos cultos afro-brasileiros, especialmente as práticas de origem Bantu, e os processos de adaptação e apropriação que aconteceram no contexto do Brasil tendiam a ser percebidos como degradações contaminadas pelos processos da colonização e da escravidão. Nessa perspectiva, a fotografia e seus usos, vistos como não autênticos, eram considerados pouco interessantes.

O pano de fundo dessa rejeição é uma perspectiva teórica baseada numa série de oposições conceituais que contrapõem o primitivo ao moderno, a África ao Ocidente, a oralidade à escrita. Na década de 1970, na esteira da descolonização dos países africanos, a oralidade, em particular, foi abraçada pela antropologia como uma marca identitária de africanidade, enquanto a escrita, em contraste, era interpretada como uma imposição colonial. De acordo com Jacques Derrida (1976), os pressupostos antropológicos sobre a oralidade e a escrita seguem um tropo que percorre o pensamento ocidental desde os tempos de Platão, que argumentava que a palavra pronunciada era carregada de uma vitalidade completamente ausente na escrita. No trabalho de Juana Elbein - talvez a mais zelosa de todos, na reificação da oralidade - a influência dessa lógica é nítida. Ressaltando o papel da oralidade na preservação da cultura afro-brasileira, Elbein (1984) defende que o uso da escrita vai, fundamentalmente, na contramão dos valores epistemológicos do candomblé. Nessa perspectiva - que tem repercutido bastante nos estudos sobre as religiões afro-brasileiras -, a ênfase na oralidade como meio exclusivo da transmissão do saber religioso também rejeita, implicitamente outros registros,

\footnotetext{
${ }^{5}$ Para análises, ver Dantas (1988) e Capone (2005).
} 
como fotografias, gravações de som e filmes. ${ }^{6}$

A fotografia em particular, celebrada por intelectuais como Walter Benjamin (1968) como catalisador da modernidade artística ocidental, tem sido alvo de muitas críticas em relação à representação do negro. Nisso, pesam muito as imagens estereotipadas mencionadas acima (MONTES E ARAÚJO, 2000; LISSOVSKY E AZEVEDO, 1988). Esses questionamentos sobre a fotografia do negro no sentido mais amplo parecem ser apoiados pela existência, hoje em dia, de restrições à fotografia em quase todos os terreiros mais antigos. Nos últimos anos, vêm aumentando as tensões sobre o papel da imagem fotográfica em comunidades de candomblé, agravadas por políticas culturais que consideram os terreiros de candomblé como pontos obrigatórios no roteiro de turismo cultural. Junto às paisagens tropicais de praias rodeadas por coqueiros, a arquitetura colonial, o axé music e o Carnaval, as cerimônias de candomblé se tornaram mais uma das atrações imperdíveis da Bahia. Visitantes de outros países e de outros estados do Brasil vêm chegando aos terreiros em números cada vez maiores, levados por guias profissionais e com o objetivo de voltar para casa com mais uma lembrança de suas férias na Bahia: a prova fotográfica de ter presenciado um transe verdadeiro. Nos terreiros considerados mais tradicionais, a luta dos ogãs para impedir a realização dessa meta é tão constante que quase chega ao ponto de parecer uma parte periférica do ritual. A intensidade desses confrontos, às vezes acirrados e envolvendo a apreensão de equipamentos, parece reforçar a sabedoria popular segundo a qual a fotografia é uma prática completamente alheia, tabu, ou, na melhor das hipóteses, altamente indesejável no universo do candomblé.

Como constatamos acima, a literatura etnográfica sobre o candomblé, na sua maioria, tem se calado sobre a questão da fotografia nos terreiros. Desde o trabalho de Nina Rodrigues até outros estudos mais recentes, como os de Thompson (1983, 1993) e Omari-Tunkara (2005), as discussões sobre a iconografia das religiões afro-brasileiras têm-se concentrado em linguagens que remontam à África, como esculturas em madeira ou metal, contas, bordados e têxteis. Quando a fotografia vem à baila, é geralmente citada em relação à antipatia que os

\footnotetext{
${ }^{6}$ No trabalho de Muniz Sodré e de Marco Aurélio Luz, por exemplo, o uso da escrita aparece como incompatível com a transmissão oral do saber. Cf. Sodré (1988) e Luz (2000). Já Júlio Braga aponta para um grau de coexistência entre a oralidade e a escrita no candomblé, observando que "para o povo de santo, qualquer recurso é válido para ampliar o conhecimento do universo mágico-religioso, mesmo que se manifestem contrariamente a tais atitudes" (BRAGA, 2000: 88).
} 
terreiros têm a ela, como em uma carta, de 1936, do folclorista Edison Carneiro. Nessa carta, dirigida ao pesquisador Arthur Ramos, Carneiro menciona ter tirado fotos do assentamento de um orixá e de alguns objetos rituais, observando que as imagens iriam "fazer um furor" se fossem publicadas: (OLIVEIRA e LIMA, 1987: 103). No entanto, um olhar mais atento revela que, nos terreiros de candomblé, há uma diversidade de opiniões sobre a fotografia. São marcadas por complexas nuances e ambivalências, mas nem todas são negativas.

\section{A FOTOGRAFIA NOS TERREIROS: OS USOS "DE DENTRO" E OS "DE FORA"}

Na verdade, o grau de rejeição ou aceitação da fotografia no mundo do candomblé não é redutível a uma simples oposição binária entre a suposta pureza africana e sua degenerescência moderna. Pelo contrário, envolve uma série de processos complexos de adaptações e ressignificações dentro de uma cosmogonia híbrida, com algumas raízes na África e outras no Brasil. As atitudes em relação à fotografia no candomblé são inseparáveis da conjuntura sociopolítica e suas transformações ao longo do tempo. A fotografia tem sido utilizada - e valorizada - nos terreiros há pelo menos um século, inclusive naqueles que mais restrições têm a ela, onde imagens de um gênero específico - retratos posados - estão muito em evidência. Diversos exemplos antigos podem ser encontrados, como nesta imagem tirada por Pierre Verger, no final dos anos 1940, de um jovem sacerdote chamado Manoel Rufino durante uma cerimônia pública. 


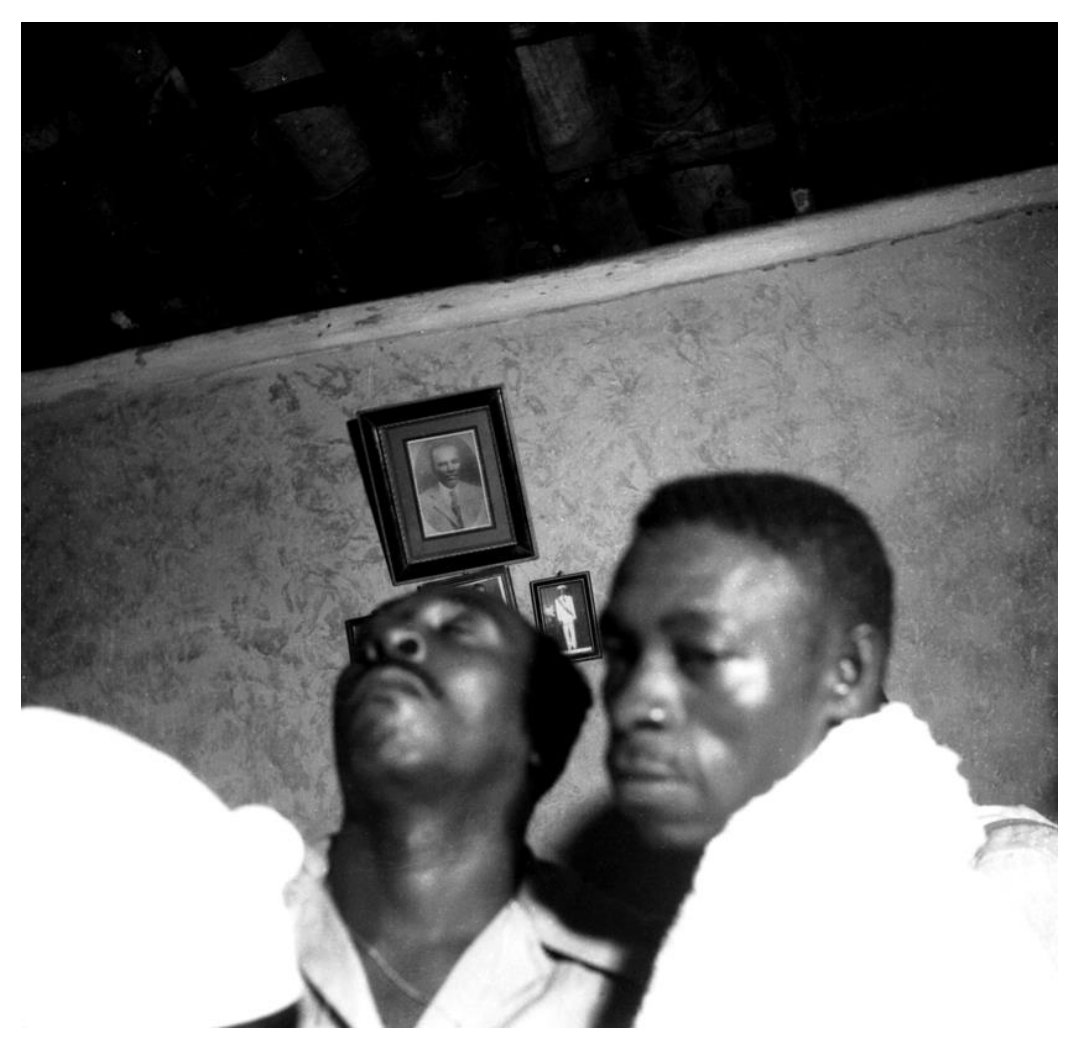

Figura 6: Rufino. Pierre Verger, 1946-1950. Usada com permissão da Fundação Pierre Verger, Salvador, Bahia.

Como outros etnofotógrafos, Verger tinha um fascínio especial por imagens de transe, e nessa foto, ele provavelmente pretendia registrar o barravento de Rufino, o momento em que ele incorporou o orixá. A imagem de Rufino, entretanto, ficou desfocada e os olhos do espectador são guiados para a parede no fundo, onde, perfeitamente focadas, estão quatro fotografias emolduradas. Duas estão cobertas pela cabeça de Rufino, mas as outras são bem visíveis. A maior é um retrato de busto de um homem de meia-idade vestindo terno e gravata, reconhecível como Miguel Arcanjo ou Massanganga, o pai de santo que iniciou Rufino. ${ }^{7}$ A menor mostra o corpo inteiro de um homem com um terno branco e chapéu, com uma faixa diagonal ao tronco, do ombro à cintura - o traje cerimonial de um ogã, cargo ocupado por iniciados do sexo masculino que não recebem o orixá. A localização proeminente, no barracão do terreiro, de fotos desses indivíduos de óbvia importância na comunidade religiosa sinaliza a valoriza-

\footnotetext{
${ }^{7}$ Segundo um de seus descendentes espirituais, Miguel Arcanjo era de raiz Bantu, especificamente de uma nação pouca conhecida, amburaxó. Tinha terreiro no antigo bairro de Beiru, hoje Tancredo Neves (Entrevista com Eldon Araújo Laje. Salvador, Bahia, janeiro de 2006). Sobre o nome africano de Miguel Arcanjo ver Amado (1967).
} 
ção de retratos fotográficos como forma de representação.

É interessante constatar que no início da década de 1940 Rufino tinha sido alvo de perseguição policial. Em 17 de fevereiro de 1941, uma cerimônia no seu terreiro na Estrada da Liberdade foi invadida por um batalhão que prendeu mais de vinte indivíduos, pessoas da plateia e da casa, que passaram pelo menos uma noite na delegacia. O jornal A Tarde fez duas matérias sobre o acontecimento, com diversas fotos das pessoas presas, entre elas o próprio Rufino.

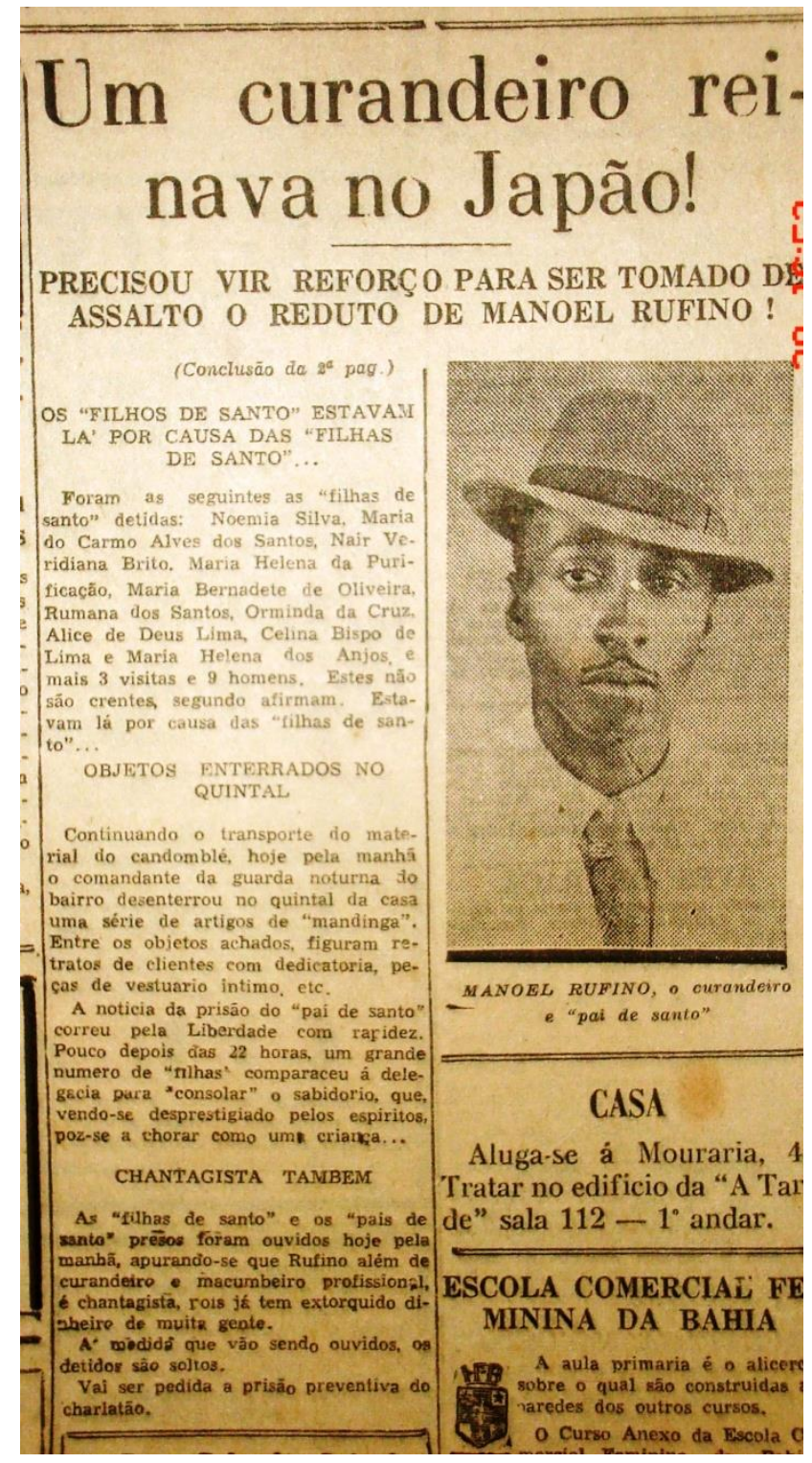

Figura 7: Matéria sobre a invasão policial no terreiro de Rufino. A Tarde, 18/2/1941, p. 2. 
Por causa desse incidente, Rufino transferiu sua casa de culto para o bairro do Beiru, na época, um lugar afastado da cidade. ${ }^{8}$ Entender essa trajetória é importante para refletirmos sobre a sua decisão, alguns anos depois e não obstante as mágoas dessa experiência com a visibilidade pública, de permitir que Verger e posteriormente ainda outros fotógrafos fizessem imagens de cerimônias no seu terreiro. Obviamente, Rufino entendia que o problema da fotografia dependia muito de quem estava atrás da câmera.

Hoje, Rufino e Miguel Arcanjo são lembrados como sacerdotes que não hesitavam de introduzir inovações na sua prática religiosa, o que torna tentador concluir que sua aceitação da fotografia tenha pouco a ver com as atitudes dos terreiros considerados mais tradicionais. No entanto, outra imagem de Verger, feita por volta do mesmo período, mostra uma fotografia exposta em uma comunidade religiosa renomada por sua fidelidade às práticas africanas, o Ilê Axé Opô Afonjá.

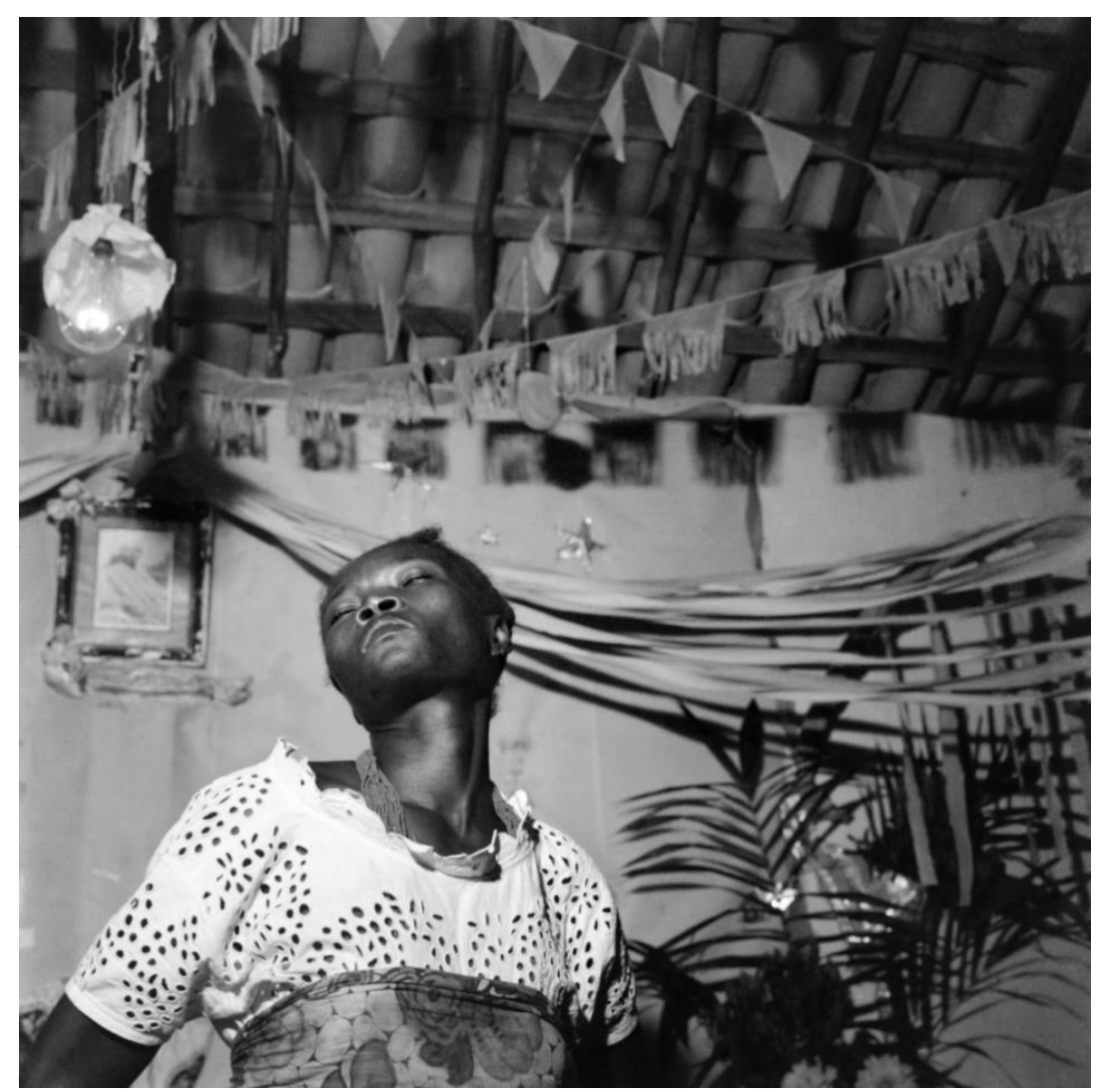

Figura 8: Iaô incorporada por seu orixá, no Ilê Axé Opô Afonjá. Pierre Verger, 1950s. Usada com permissão da Fundação Pierre Verger, Salvador,

\footnotetext{
${ }^{8}$ Entrevista com Eldon Araújo Laje. Salvador, Bahia, janeiro de 2006. O bairro de Beiru é conhecido hoje como Tancredo Neves.
} 
Mais uma vez, o olhar do etnógrafo é atraído para uma cena de possessão: uma jovem adepta que acaba de receber seu orixá. Com os olhos fechados, os braços levemente jogados para trás e apoiados sobre os quadris - linguagem corporal que sinaliza a presença da divindade -, ela inclina a cabeça para trás e para a direita, como se estivesse a guiar os olhos do observador a uma fotografia emoldurada na parede às suas costas. A falta de foco torna a imagem de fundo indistinta, mas um espectador familiarizado com a história do terreiro pode reconhecer ali um retrato da fundadora, Eugênia Anna dos Santos, conhecida como Mãe Aninha. Nascida na Bahia em 1869, filha de africanos libertos, Aninha é famosa por sua determinação em permanecer fiel às tradições dos ancestrais.

O terreiro do Opô Afonjá possui vários outros retratos de Aninha, alguns tirados em idade avançada, por antropólogos, mas outros feitos na sua juventude, bem antes do surgimento da pesquisa etnográfica sobre o candomblé. Recentemente - no acervo da antropóloga Ruth Landes, que realizou trabalho de campo na Bahia, em 1939, logo após a morte de Aninha -, me deparei com o original da foto mais antiga dela que se conhece. Em formato grande, em papel cartão já ressecado e rachado pelos estragos do tempo, mostra Aninha como uma jovem mulher, elegantemente vestida com uma blusa branca rendada, saia rodada e pano da costa, usando vários anéis, pulseiras e colares, estes últimos de um tipo característico de membros de irmandades católicas. 


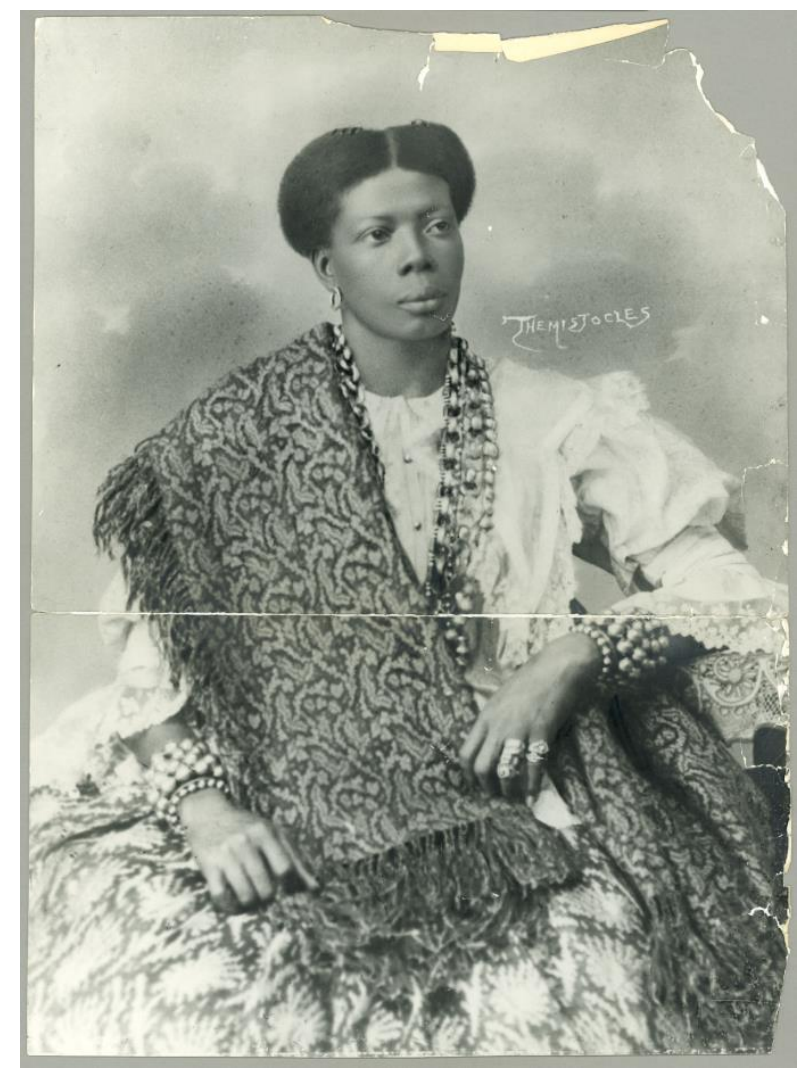

Figura 9: A fundadora do Ilê Axé Opô Afonjá, Eugênia Anna dos Santos, Mãe Aninha, provavelmente ca. 1890. Usada com permissão da Smithsonian Institution, Washington, D.C., National Anthropological Archives, Ruth Schlossberg Landes Papers.

$\mathrm{Na}$ etnografia que Landes escreveu sobre seu tempo na Bahia, A Cidade das Mulheres, Aninha é mencionada diversas vezes, idealizada pela autora e por seus informantes (especialmente Martiniano do Bonfim), por sua pureza ritual. Curiosamente, Landes não fala desta fotografia nem de qualquer outra de Aninha. No entanto, Landes reserva um parágrafo inteiro para uma foto de Pulquéria, segunda ialorixá de outro terreiro histórico, o Gantois. Escrevendo sobre seu primeiro encontro com Mãe Menininha, sobrinha-neta de Pulquéria e, então, mãe de santo do terreiro, a antropóloga registra seus comentários sobre aquela foto:

Naquela primeira tarde, [Mãe Menininha] falou sobre seus ancestrais: - Esta casa pertenceu a minha tia, disse, olhando em volta da sala e para o retrato oval de mulher que pendia da parede oposta. - Chamava-se a Grande Pulquéria — [...] Examinei novamente o retrato, reparando no torso de fazenda africana listrada, o vestido de dona-de-casa da casa baiana, as pulseiras de ouro, grossas como algemas da era elizabetana, em cada braço, os colares de contas rituais, os pesados brincos de ouro 
aparecendo por baixo do torso. Via-se que era uma mulher abastada, que jamais fizera trabalho subalterno ou escravo [...] Durante os ritos do templo [Menininha] sempre se curvava ante os retratos e as relíquias da tia e ante as filhas, mas não se curvava ante ninguém mais. (LANDES, 2002: 126-27).

Essa descrição ressalta a importância que a fotografia de Pulquéria tinha para Mãe Menininha. Além de exibir a foto publicamente como um objeto de valor e importância, Menininha ainda fazia reverência a ela, curvando seu corpo de acordo com o costume iorubá, rigorosamente preservado no candomblé, ao saudar uma pessoa mais velha. ${ }^{9}$ Duas décadas antes da viagem de Landes a Bahia, a mesma foto de Pulquéria havia sido publicada por Manuel Querino, na sua monografia, A raça africana e seus costumes na Bahia (1917). No mesmo texto, Querino também incluiu um retrato da nagô liberta Maria Júlia da Conceição, mãe de sangue de Pulquéria, que, segundo a memória oral, fundou o Gantois por volta de 1849 (NOBREGA e ECHEVERRÍA, 2006).

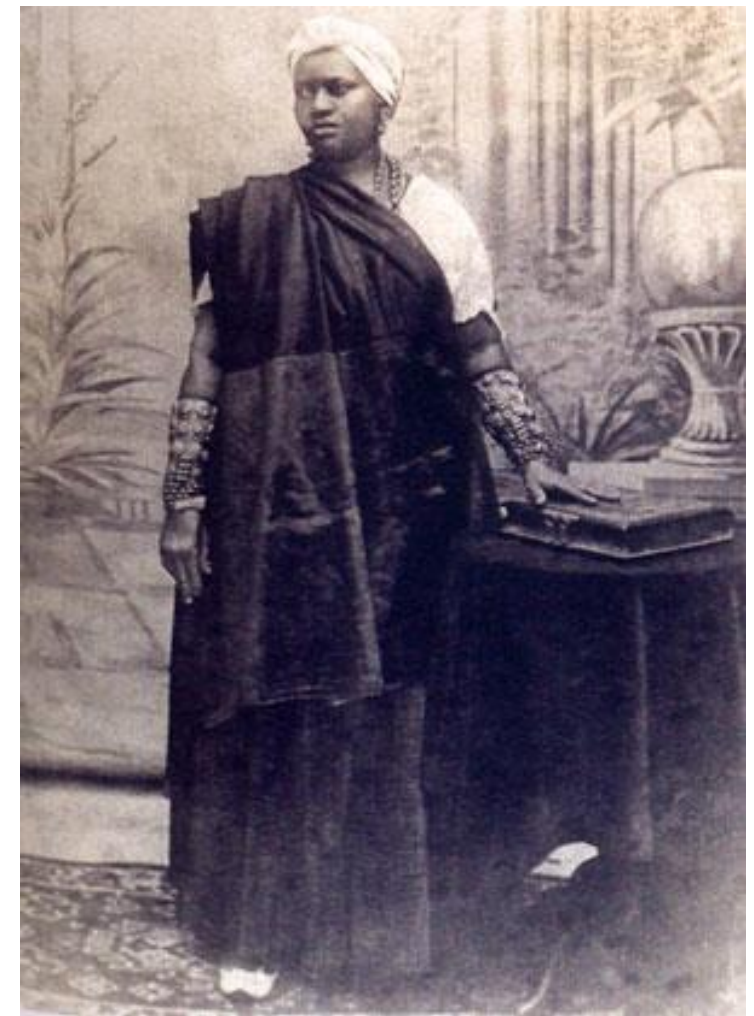

Figura 10: Maria Pulquéria da Conceição Nazaré, segunda mãe de santo do Gantois. Coleção do Instituto Geográfico e Histórico da Bahia, Salvador, Bahia.

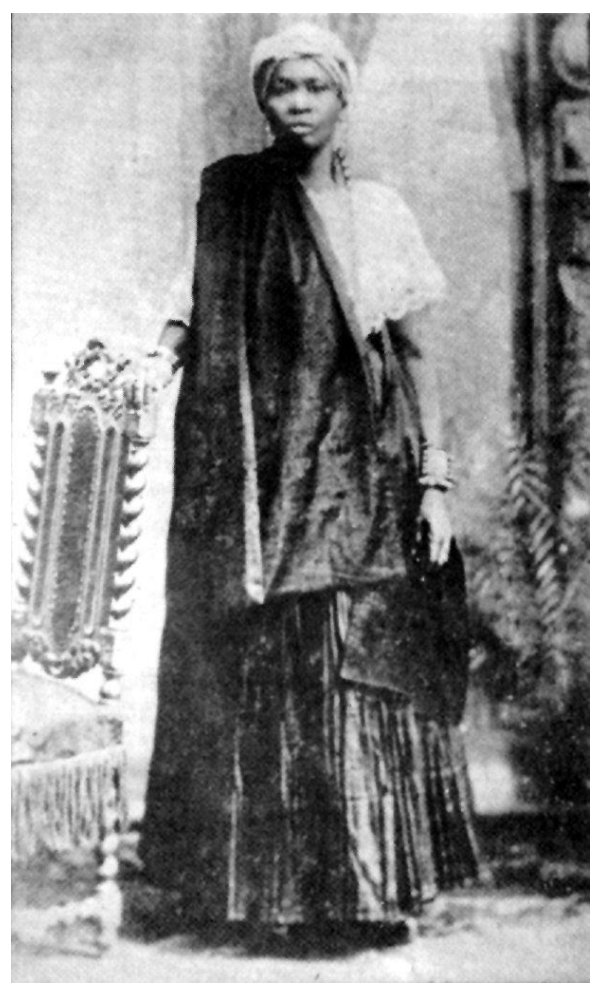

Figura 11: A nagô liberta Maria Júlia da Conceição, fundadora do Gantois e mãe de sangue de Pulquéria. Coleção do Instituto Geográfico e Histórico da Bahia, Salvador, Bahia.

\footnotetext{
${ }^{9}$ Contudo, estranhamos a afirmação no mesmo trecho do livro de Landes, de que Menininha também se curvava ante suas filhas. De acordo com os costumes iorubás e afro-brasileiros, são as filhas, por serem mais novas, que têm que se curvar, para mostrar respeito à mãe.
} 
De acordo com a tradição oral, Maria Júlia morreu em 1910, o que significa que sua fotografia foi tirada anos antes de Querino publicá-la. Muito provavelmente, seu retrato e o de sua filha - como o de Aninha na juventude - tenham sido tirados por iniciativa própria das sacerdotisas. Hoje, no barracão do Gantois, as imagens centenárias de Pulquéria e sua mãe ocupam lugares de destaque - ao lado de cartazes avisando que é proibido fotografar.

A publicação dessas fotos por Manoel Querino deixa claro que não era que os primeiros etnógrafos simplesmente ignorassem os usos da fotografia nos terreiros: Querino, pelo menos, não apenas sabia que havia fotografias, como até se apropriou de algumas para ilustrar sua monografia. Contudo, há, em geral, diferenças estilísticas importantes entre o tipo de fotografia usado para ilustrar os trabalhos de antropólogos e as imagens que são valorizadas nos terreiros. O contraste é aparente desde as primeiras fotos etnográficas publicadas por Nina Rodrigues na década de 1890, retratando amuletos, esculturas e ferramentas rituais.

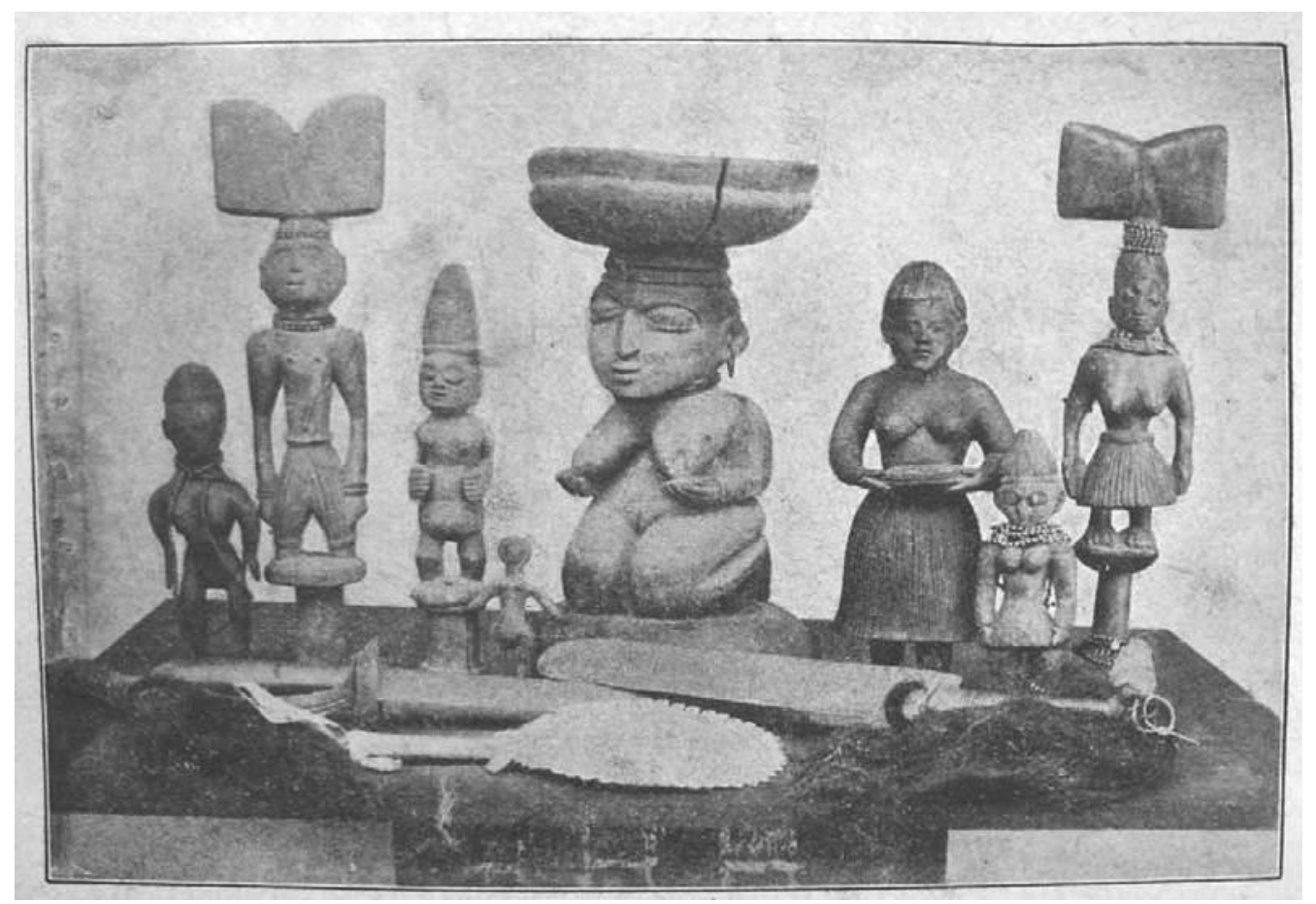

Figura 12: Esculturas e objetos rituais do candomblé, ca. 1900. Publicado em 1932, em Nina Rodrigues, Os africanos no Brasil.

O desenvolvimento de câmeras mais sofisticadas, filmes de maior sensibilidade e, principalmente, a introdução do flash de magnésio na década de 1930 reduziram significativamente as dificuldades técnicas de captura de movimento de pessoas em ambientes de pouca luz. 
Pontos de Interrogação, v. 3, n. 2, jul./dez. 2013

Revista do Programa de Pós-Graduação em Crítica Cultural

Universidade do Estado da Bahia (UNEB), Campus II - Alagoinhas - BA

Esses avanços tecnológicos trouxeram a possibilidade de fazer imagens de rituais enquanto aconteciam, mesmo quando a pessoa fotografada não parava para facilitar a foto. Para antropólogos que buscavam representar os objetos de estudo como se não tivesse influências externas, essa possibilidade era mais do que bem-vinda. Assim, a partir da década de 1950, a representação fotográfica de pessoas em transe se consolidou como paradigmática na etnografia visual do candomblé, em grande medida graças à obra de fotógrafos como Pierre Verger e José Medeiros (VERGER, 1954; MEDEIROS, 1957).

Enquanto os estudiosos deslocavam sua atenção cada vez mais para o transe e outras imagens de rituais, mantinha-se, nos terreiros, a preferência preexistente por imagens feitas fora do âmbito ritual. As fotos exibidas nas paredes dos barracões e dos espaços interiores dos terreiros são retratos posados de ialorixás e babalorixás, passados e presentes, cujo pleno consentimento para a presença do fotógrafo e o ato de fotografar é sinalizado pela postura corporal, geralmente sentados, sempre com olhos direcionados para a câmera, e pela escolha das vestimentas: o elegante traje ritual usado durante a parte inicial da cerimônia, o xirê. Nas fotos que enfeitam as paredes dos terreiros, sobretudo os mais antigos, jamais se encontram imagens de devotos em transe ou usando as vestimentas próprias ao orixá manifestado.

Estas escolhas estéticas fornecem importantes esclarecimentos sobre os códigos epistemológicos que governam não apenas registros fotográficos, mas também documentos escritos e até mesmo a circulação oral do conhecimento religioso. Certos aspectos deste saber são de acesso restrito, disponíveis apenas para pessoas que fazem parte dos escalões superiores da hierarquia religiosa. Não importa o meio da transmissão de informações relativas ao espaço ritual; é sempre preciso evitar a possibilidade de acesso não autorizado aos fundamentos do saber religioso, considerados secretos. Após um período de observação, os mais velhos escolhem individualmente os novos iniciados que são aptos a receber elementos desse conhecimento, compartilhando-o pouco a pouco, passo a passo, ao longo de anos. Nesta perspectiva, publicações escritas, exposições de fotografia, gravações de áudio e filmagens, sobretudo quando são disponibilizados a qualquer um através de comercialização ou na Internet, são extremamente problemáticas. Não é apenas pelo fato de existir um registro. Mais importante ainda é a questão de onde irá circular e quem terá acesso.

O que está por trás das restrições à fotografia não é, fundamentalmente, um tabu genera- 
lizado em relação à imagem fotográfica em si, mas a lei do segredo, que regula a transmissão e circulação do conhecimento do sagrado em todas as modalidades - inclusive quando as informações são passadas oralmente. Neste sentido, é ilustrativo retornar mais uma vez ao caso das fotografias das primeiras ialorixás do Gantois, as quais, cuidadosamente emolduradas, dividem a parede do barracão com um cartaz advertindo que fotografar não é permitido. Esta contradição aparente, na verdade, obedece a uma consistente lógica interna. Não é que todas as fotos sejam proibidas. Pelo contrário, a proibição da fotografia é apenas um mecanismo para impedir os instantâneos de determinadas pessoas, especialmente as de fora, assim garantido que a comunidade religiosa mantenha o controle sobre a produção e circulação de imagens (CASTILLO, 2008).

A valorização do retrato posado no candomblé é ilustrativa da importância dos antepassados na cosmologia religiosa. Em seu estudo sobre o culto aos ancestrais na Bahia, Elbein (1984) enfatiza a importância fundamental do conceito iorubá de așe, que existe também no candomblé e é grafado no Brasil como axé. Energia vital que impulsiona o universo, o axé é encontrado em todos os seres vivos em diferentes quantidades. Os orixás o possuem em abundância, e quando eles descem ao mundo dos seres vivos, o aiyê, por meio de seus devotos, parte de seu axé é absorvido pelas pessoas presentes, especialmente os médiuns e membros do público que fazem contato físico com o orixá manifestado. Quando morre um dos mais velhos da comunidade religiosa, sua alma passa para o orun (o mundo dos espíritos), e seu axé individual é acrescentado ao axé coletivo do terreiro. Assim, quanto maior e mais velho o terreiro e quanto mais fielmente seus devotos cultuem os orixás, maior será o axé coletivo.

Do ponto de vista semiótico, os retratos dos ialorixás e babalorixás dos tempos passados funcionam como signos que lembram ao espectador seu axé e o capital simbólico que isto representa para o terreiro. Invocando a memória dos ancestrais que já partiram para o orun, estas imagens catalisam a comunicação entre os seres vivos e o mundo dos espíritos. Ao olhar nos olhos daqueles que foram os pioneiros na reconfiguração das religiões africanas no Brasil o espectador pode entrar no mundo daqueles cujos primeiros passos foram dados em solo africano e cujas primeiras palavras foram ditas na língua dos cânticos que entoavam quando faziam as oferendas aos orixás.

A ideia de que a fotografia pode esbater a fronteira que separa os vivos e os mortos não 
é exclusiva da religião afro-brasileira, é também sugerida pelo pós-estruturalista francês Roland Barthes. No seu influente texto sobre a fotografia, Câmera Clara (1981), Barthes medita sobre o poder de antigas fotografias de chamar o espectador para uma era distante, citando o sentimento de espanto que o dominou quando, olhando uma foto do irmão de Napoleão, percebeu que estava "olhando nos olhos que tinham olhado para o Imperador" (1981: 3). Quando Barthes escreveu esse livro, sua mãe tinha falecido há pouco tempo e o autor menciona este evento repetidamente em seu texto. Ele escolhe o termo espectro para se referir à pessoa ou coisa fotografada "porque esta palavra retém, por sua etimologia, uma relação com o espetáculo e aumenta aquela coisa terrivel que existe em cada fotografia: o retorno dos mortos" (1981: 9, grifos meus). Christopher Pinney (1992), aplicando a teoria semiótica de C.S. Peirce à imagem fotográfica, sugere que as fotografias, além de serem ícones - imagens que se assemelham fisicamente seus referentes - são também indícios, porque contêm os traços físicos daqueles referentes: "O esqueleto seco de uma folha, e a impressão da luz sobre produtos químicos na superfície de [uma] fotografia impressa a albúmen... são, em termos peirceanos, a mesma coisa" (1992: 77). Comparando uma fotografia a um "esqueleto ressecado", ele cita a definição poeticamente incisiva de Susan Sontag: "uma fotografia não é apenas uma imagem (como uma pintura é uma imagem), uma interpretação do real, é também um traço, estampado diretamente do real, como uma pegada ou uma máscara de morte [...] um vestígio material do seu referente" (SONTAG, 1977: 154).

No candomblé, a intensa valorização de retratos dos antepassados pode ser entendida como um reconhecimento da preservação, nessas imagens, de vestígios reais do falecido. Mas, nos terreiros mais antigos, paralela à reverência a esse tipo de imagem há uma aversão às imagens de transe, tão caras a turistas e antropólogos. Quando perguntei sobre esse receio, as respostas, muitas vezes, foram colocadas em termos que lembraram a oposição platônica entre o dinamismo da experiência vivenciada e a inércia da cópia. Um pai de santo de nação angola, Luciano, me disse:

O orixá não tem que ser fotografado. Porque, o que você pode analisar em nível de uma manifestação? É um estado, um momento, uma sublimação, uma passagem. Você tem que ter registro da essência, do que o orixá passou para você. O orixá é natureza, é sentimento, é luz. Então, você tem que receber aquela energia, e não fotografar aquela imagem porque "estava lindo". Não! Aquilo não tem que ficar registrado, tem que ficar na mente, no mo- 
mento, no ar. [...] Se você quer fotografar uma árvore, tudo bem, é um objeto material. Mas você vai conseguir fotografar o vento? Você pode fotografar um furacão, um twister? E o orixá é o quê? O orixá é vento, é espírito, é essência! Então, ele não quer ser fotografado! E eu acho que fotografá-lo é uma agressão.

Para Luciano, as tentativas de registrar a presença do orixá através da fotografia são, em última instância, inúteis, pois a câmera não consegue capturar o mais importante da experiência: a energia transcendental da entidade. Essa energia, transmitida às pessoas que presenciam a cerimônia, escapa da máquina fotográfica, que registra apenas os elementos visíveis da experiência. O que aparece na fotografia é apenas o corpo inerte do médium.

No entanto, em muitos terreiros mais novos, fotografias de transe provocam uma reação diferente. Sem um acervo precioso de fotos antigas que relembrem a sucessão de gerações que remonta a ancestrais nascidos na África, casas mais novas frequentemente demonstram um entusiasmo por fotografia e filmagem, como se a acumulação de um arquivo visual pudesse ajudar a construir um passado, mesmo que esse passado seja apenas de uma década ou um ano. Como Sontag (1977) observa, além de simplesmente registrar o passado, a fotografia também serve para criá-lo, ao cristalizar um momento específico, separando-o de uma série infinita de outros que, por não serem registrados, desvanecer-se-ão nos recessos da memória.

Esta maior permissividade em relação à fotografia ainda tem a ver com a questão do controle sobre a imagem. Ao contrário dos terreiros históricos, cujo renome vem atraindo estudiosos, jornalistas e turistas há décadas, terreiros mais recentes tendem a receber poucos visitantes de fora. Quando surge o assunto de tirar fotos, o fotógrafo geralmente já tem vínculos com comunidade - um amigo ou parente que pretende entregar as imagens à própria casa para serem acrescentadas aos álbuns de fotos de outros eventos vivenciados conjuntamente, como festas de aniversário, casamentos e formaturas (VAN DE PORT, 2006). Contudo, embora a maioria dos terreiros mais novos tenha uma visão menos rígida do segredo, ele ainda existe. Somente as partes públicas da cerimônia podem ser fotografadas. Fotografias de rituais privados, como iniciação e sacrifício, não são permitidas.

\section{OUTROS USOS DA FOTOGRAFIA: COMUNICAÇÃO COM O MUNDO DOS ESPÍRITOS}


Pontos de Interrogação, v. 3, n. 2, jul./dez. 2013

Revista do Programa de Pós-Graduação em Crítica Cultural

Universidade do Estado da Bahia (UNEB), Campus II - Alagoinhas - BA

Para Barthes (1981), o sentimento de proximidade com o passado que a fotografia de alguém que já morreu evoca é, no fim de contas, ilusório, pois a pessoa cuja imagem está congelada no papel continua a fugir ao nosso alcance. De qualquer modo, no candomblé, a instabilidade da barreira entre o mundo dos vivos e o mundo dos espíritos constitui parte fundamental da cosmologia religiosa. A própria incorporação do orixá, vodun ou nkisi por um devoto - uma ocorrência diária - é um exemplo da manifestação, no aiyê, de um ser que reside no orun. Outros visitantes frequentes no aiyê são os caboclos, espíritos de indígenas, os erês (espíritos infantis) e os eguns (espíritos de mortos). Estas entidades podem chegar de forma inesperada, por vontade própria, mas também vêm quando são invocados através de preceitos específicos. Nos rituais que envolvem eguns, fotografias do falecido podem desempenhar um papel, o que reforça a ideia de que a imagem fotográfica de alguém é um índice daquela pessoa, contém um traço físico dela.

Essa característica da fotografia é importante para entender o seu uso num certo tipo de ebó (oferenda). Em ebós para resolver situações que envolvam pessoas além daquela que oferta o ebó, fotografias dessas outras pessoas são muitas vezes utilizadas, juntamente com seus nomes. Verger (1995), descrevendo este tipo de ebó entre os iorubás na África Ocidental, menciona peças de roupa e cortes de cabelo ou de unha, bem como o nome pronunciado. No Brasil, esses elementos também aparecem, mas o nome é geralmente escrito. No estudo africano de Verger, fotografias não são mencionadas, mas elas são muito utilizadas no Brasil há mais de um século. Escrevendo na virada do século XX, João do Rio (2006 [1904]) mencionou o uso de fotografias em ebós de amarração, ou seja, para resolver casos de amor não correspondido.

Em um dos casos que presenciei, o nome escrito foi usado por uma velha sacerdotisa na preparação de um ebó para uma jovem que estava sendo intimidada no trabalho por seu chefe. A sacerdotisa mandou sua cliente escrever o nome completo do chefe em uma pequena tira de papel, seguido pelo nome dela mesma, mas em letras maiores, mais escuras e sobrepostas ao primeiro, criando assim uma espécie de palimpsesto que simbolizava a vitória da jovem no conflito. Em seguida, fez um corte longitudinal em um pepino - que na gíria é sinônimo de problema - dentro do qual ela colocou o papel. Depois, ela instruiu sua cliente a guardá-lo no congelador de sua casa, para esfriar o conflito. A utilização de elementos do cotidiano, como pepinos e congeladores, como parte do conjunto metafórico do ebó ilustra a criatividade e 
plasticidade desse preceito mágico-religioso. Para usar uma analogia linguística, se a sintaxe do ebó é africana, seu léxico se atualiza constantemente, de forma híbrida.

A fotografia também é bastante utilizada em ebós, com uma função semelhante à do nome escrito. Em um ebó para reunir um casal depois de uma briga, usa-se a fotografia e o também nome, para intensificar a eficácia do preceito: "Coloque uma fotografia do casal em um prato raso, cobrindo-a com açúcar e arroz. Acrescente duas velas, em cada escrito o nome de uma das pessoas. Amarre-as junto com uma fita e deixar tudo na praia”. A simbologia aqui é clara: as velas representam as almas do casal, a fita que amarra as velas é a sua união, enquanto o açúcar é a doçura desejada no relacionamento. $\mathrm{O}$ arroz sugere uma alusão ao uso habitual deste grão no final de cerimônias de casamento. O motivo para levá-lo à praia, depois de arrumar, é para acionar o auxílio de Iemanjá, orixá do mar, representada ora como sereia, ora como mulher sedutora, que, acredita-se, possui conhecimentos profundos do amor e da arte de conquistar o coração de alguém. ${ }^{10}$

Assim como os ex-votos do catolicismo popular, que retratam o solicitante, o problema e sua resolução, os componentes de ebós para situações que envolvem terceiros também representam as partes envolvidas e o resultado desejado. No entanto, enquanto os ex-votos são criados posteriormente, como gratidão por uma intervenção que já aconteceu, o ebó geralmente solicita assistência futura. Por isso, os ingredientes são escolhidos para comunicar à divindade o que precisa ser feito.

Pode-se supor que as fotografias, cortes de unha etc. funcionem como outros ingredientes, como pepinos, freezers, açúcar e afins: como alegorias para diferentes aspectos da situação. Acredito, porém, que sua função é um pouco diferente. Cortes de unhas e cabelos não podem ser de qualquer um, devem pertencer à pessoa em questão, do mesmo modo que a roupa - idealmente, uma peça de vestuário que foi usada muitas vezes e não foi lavada desde a última utilização. Esses elementos, como fotografias, contêm vestígios materiais do indivíduo singular que auxiliam no direcionamento da força do ebó para ele ou ela. Segundo a ebome Donazinha, a fotografia de uma pessoa é "o retrato da sua alma", e "mais forte do que uma

${ }^{10}$ Os ingredientes de ebós que envolvem terceiros são distintos dos de ebós com o objetivo mais geral de ganhar a boa vontade de uma entidade. Ingredientes para o último tipo geralmente consistem em seus alimentos preferidos, às vezes incluem também seus objetos favoritos - charutos, moedas e bebidas alcoólicas, no caso de Exu, ou, espelhos, perfumes e sabonetes para Iemanjá ou Oxum. 
Pontos de Interrogação, v. 3, n. 2, jul./dez. 2013

Revista do Programa de Pós-Graduação em Crítica Cultural

Universidade do Estado da Bahia (UNEB), Campus II - Alagoinhas - BA

certidão de nascimento". Essa analogia sugere um conceito de fotografia que é influenciado por seus usos no Estado moderno, em que a visibilidade do indivíduo ao governo e sua identificação através de cédulas de identidade com números e fotografias são mecanismos de controle social (SONTAG, 1977; FOUCAULT, 1995).

A ideia de que a fotografia de alguém pode servir para obter poder sobre essa pessoa claramente aumenta a desconfiança em relação a estranhos que vêm querendo tirar fotos. A preocupação com as possíveis consequências de fotografias caírem nas mãos erradas vai muito além de considerações epistemológicas sobre imagens de rituais que desvelam certas questões religiosas. Também se estende ao retrato posado, um gênero que, como vimos, não revela nenhum fundamento do candomblé. Ambos os tipos de imagens - de rituais e retratos posados - podem ser usadas em ebós que, além de resolver problemas como brigas entre amantes e chefes irritáveis, também podem atuar para fins malévolos, ou seja, feitiços. De acordo com Donazinha, o medo de feitiçaria explica a aversão a fotografias de pessoas em transe: "porque com uma fotografia dessa, alguém poderia fazer coisas para mandar o orixá para longe da pessoa e nunca mais voltar."

\section{O ORUN, O AIYÊ E A FOTOGRAFIA: ALGUNS PARALELOS}

A ameaça de feitiçaria presente nas comunidades de candomblé vem daqueles que empreendem as forças do orun para o mal. Mas, historicamente, no aiyê, havia também uma ameaça paralela: a perseguição, sancionada pelo Estado, aos cultos afro-brasileiros. Assim como uma fotografia de alguém em transe poderia ser utilizada num ebó para fazer seu orixá "ir embora e nunca mais voltar", a mesma fotografia, nas mãos da polícia, podia precipitar a sua prisão, sob a acusação de feitiçaria.

Depois que o olhar etnográfico virou-se para o candomblé, nas primeiras décadas do século XX, os terreiros encontraram-se em uma encruzilhada discursiva, com profundas implicações para as suas formas de relacionamento com a imagem fotográfica. Questões de espaço não nos permitem, aqui, uma análise completa, o que se segue é apenas um breve panorama. Historicamente, a segurança dos terreiros estava na sua capacidade de permanecer invisível à polícia. O discurso etnográfico, no entanto, como uma parte das ciências humanas, estava baseado na constituição do homem como objeto de saber (FOUCAULT, 1994: 350). Subme- 
ter-se ao olhar acadêmico trazia como consequência certa visibilidade social, através dos escritos - e das fotografias - dos estudiosos. Isso, da perspectiva dos terreiros, podia ser perigoso.

Da perspectiva dos terreiros, lembrando do histórico da representação pejorativa do candomblé na sociedade baiana, sobretudo no jornalismo, se expor ao olhar etnográfico era arriscado. Mas, na visão de estudiosos como Edison Carneiro, a visibilidade proposta seria de um novo tipo. Em vez de perpetuar os velhos estereótipos de feitiçaria, curandeirismo e primitivismo, o discurso acadêmico promoveria uma visão alternativa, enquadrando o candomblé como uma religião. Era uma diferença significativa: de acordo com o Código Penal Brasileiro, feitiçaria era um crime passível de punição com pena de prisão, enquanto as religiões - todas elas - eram constitucionalmente protegidas (Dantas, 1988; Braga, 1995; Johnson, 2002; Castillo, 2008).

O Segundo Congresso Afro-Brasileiro, organizado por Carneiro em 1937, e com participação ativa de outros intelectuais baianos, entre eles Jorge Amado, parecia exemplificar os benefícios da nova visibilidade que o discurso etnográfico oferecia aos terreiros. Realizado em uma instituição acadêmica de elite e amplamente coberto pela imprensa, o evento teve a participação de intelectuais ilustres de todo o Brasil e também de um número de famosos sacerdotes e sacerdotisas do candomblé, incluindo Mãe Aninha e Mãe Menininha, que conhecemos acima na discussão sobre os retratos. A conferência resultou na elaboração de uma petição ao governador do estado, exigindo o fim da vigilância policial sobre o candomblé. Mas a maré rapidamente voltou-se contra a retórica liberal da conferência. Nesse mesmo ano, o presidente Getúlio Vargas anulou a Constituição brasileira e instalou a ditadura do Estado Novo. Os jovens intelectuais que haviam apoiado a descriminalização do candomblé no II Congresso Afro-Brasileiro tornaram-se eles mesmos perseguidos pela polícia. Em 1939, Edison Carneiro teve que fugir para o Rio de Janeiro e Ruth Landes foi "convidada" a sair do país. Em 1941, Jorge Amado foi forçado ao exílio (BRAGA, 1995; CASTILLO, 2008).

O Estado Novo terminou em meados dos anos 1940, mas as reivindicações de liberdade religiosa para os terreiros demoraram a retomar força. Em 1951, a tensão entre visibilidade e invisibilidade, para as casas de candomblé, veio novamente à tona com a publicação de extensos ensaios fotográficos em dois periódicos de destaque. Em maio, a revista francesa Paris- 
Pontos de Interrogação, v. 3, n. 2, jul./dez. 2013

Revista do Programa de Pós-Graduação em Crítica Cultural

Universidade do Estado da Bahia (UNEB), Campus II - Alagoinhas - BA

Match publicou uma reportagem do cineasta Henri-Georges Clouzot (CLOUZOT, 1951) narrando um ritual de iniciação feito no terreiro de Rufino, o mesmo pai de santo que conhecemos acima, fotografado por Verger na segunda metade dos anos 1940. Para a elite brasileira, a visão que a reportagem projetava do Brasil - retratado como uma terra primitiva onde o sacrifício de sangue era uma ocorrência diária - reforçou uma velha percepção de que a população negra era responsável pelo atraso do Brasil, impedindo-o de ser considerado pelos países do norte como um lugar civilizado. Em resposta, O Cruzeiro, a maior revista brasileira, publicou também uma matéria sobre candomblé (SILVA, 1951). Anunciada como "etnográfica", a matéria continha dezenas de imagens de iniciados banhadas em sangue, enquanto o texto habilmente apontava para a Bahia negra como a responsável pelo o estigma de fetichismo que Clouzot tinha atribuído ao Brasil como um todo. Nos terreiros, o efeito de ambas as publicações foi o mesmo: uma reafirmação da necessidade de controlar, rigidamente, o acesso ao conhecimento religioso, sobretudo quando se tratasse de fotografias (CASTILLO e PARÉS, 2006; TACCA, 2003, 2009).

Muita coisa mudou desde 1951, é claro. Na década de 1960, eventos mundiais como a descolonização da África e o movimento de direitos civis nos Estados Unidos estimularam o crescimento de uma consciência negra diaspórica. No Brasil, o preconceito contra a religiosidade afro-brasileira foi se diminuindo e, em 1976, o governo da Bahia finalmente deu fim ao controle policial sobre os terreiros. Na década seguinte, a Casa Branca se tornou o primeiro terreiro de candomblé a ser tombado pelo Instituto do Patrimônio Histórico e Artístico Nacional (IPHAN), seguido, na virada do século XXI, por vários outros. Hoje, os jornais já não publicam mais matérias pedindo a prisão de líderes do candomblé; o que sai nos jornais de hoje são elogios a sua sabedoria.

Esses eventos têm transformado o dia a dia do povo de candomblé, mas os tempos de perseguição policial ainda permanecem na memória dos sacerdotes e sacerdotisas mais velhos, influenciando suas ideias do que deve permanecer em segredo e o que pode ou não ser fotografado. A natureza sutil e metafórica das memórias da perseguição tornou-se clara para mim, um dia, durante uma conversa com Donazinha. Alguém tinha me dito que os antigos africanos ficavam invisíveis quando quisessem, mas que essa habilidade tinha-se perdido ao longo do tempo. "É verdade?" lhe perguntei. Ela olhou para mim com surpresa, quase espantada, e percebi que eu tinha tocado num assunto que não era para conversa fiada. Mas, depois 
de uma pausa, ela respondeu: "Invisível, não, minha filha... mas a pessoa ficava envultada, se transformava num vulto qualquer, como se fosse uma sombra. Havia um grande capoeirista, que morava lá pro lado das Sete Portas, que se transformava em bananeira. Eram coisas são ligadas com a polícia. Mas, hoje em dia não... Como muita coisa que existia antes, as grandes ialorixás e babalorixás levaram consigo, sem falar.”

\section{CONCLUSÃO}

As palavras de Donazinha revelam que o contexto social e o universo mitológico do candomblé não podem ser entendidos separados um do outro. Ao longo do século $\mathrm{XX}$, o candomblé tem-se transformado de uma prática marginalizada a uma pedra angular da cultura nacional. Nas atitudes contemporâneas em relação a visibilidade e invisibilidade, ao que deve e não deve ser fotografado, quem o fotógrafo é, e o que acontece com a imagem depois de feita, diversas influências diacrônicas são perceptíveis: as raízes africanas do candomblé, o contexto social em que se desenvolveu e a realidade contemporânea com que se defronta. À medida que o clima social tornou-se mais tolerante, o espaço discursivo do segredo recuou, mas não desapareceu, e hoje há muita discordância dentro do sacerdócio sobre o que pode ser tornado público e o que deve permanecer oculto. No entanto, apesar das ambivalências e diferenças de opinião a respeito do uso da fotografia, uma coisa é clara. Longe de serem categoricamente rejeitadas pelos terreiros mais vigilantes na proteção da pureza de sua prática religiosa, as imagens fotográficas têm sido usadas há mais de cem anos, integradas nos rituais e na vida social de modos que sugerem uma simbiose complexa entre tradição e modernidade.

\section{REFERENCIAS}

AMADO, Jorge. A Bahia de Todos os Santos. Rio de Janeiro: Livraria Martins, 1967.

ARAÚJO, Emanuel (org.). Negro de corpo e alma: mostra do redescobrimento. São Paulo: Associação Brasil 500 Anos Artes Visuais/Fundação Bienal, 2000.

AZEVEDO, Paulo Cesar de e Mauricio Lissovsky (org.) Escravos brasileiros do século XIX 
Pontos de Interrogação, v. 3, n. 2, jul./dez. 2013

Revista do Programa de Pós-Graduação em Crítica Cultural

Universidade do Estado da Bahia (UNEB), Campus II - Alagoinhas - BA

na fotografia de Christiano Jr. São Paulo: Editora Ex Libris,1988.

BALANTA, Beatriz Eugenia Rodríguez. Especímenes antropométricos y curiosidades pintorescas: la orquestación fotográfica del cuerpo "negro" (Brasil circa 1865). Revista Ciencias de la Salud, vol. 10, no. 2 (2012), pp. 59-78.

BARTHES, Roland. Camera Lucida: Reflections on Photography. Nova York: Hill and Wang, 1981.

BENJAMIN, Walter. The Work of Art in the Age of Mechanical Reproduction. In Hannah Arendt (org.) Illuminations: Essays and Reflections by Walter Benjamin. Nova York: Schocken Books, 1968, pp. 217-251.

BRAGA, Julio. Oritameji: o antropólogo na encruzilhada. Feira de Santana: Universidade Estadual de Feira de Santana, 2000.

—. Na gamela do feitiço: repressão e resistência nos candomblés da Bahia. Salvador: Edufba, 1995.

CAPONE, Stefania. A busca da África no candomblé: tradição e poder no Brasil. Rio de Janeiro: Editora Pallas, 2005.

CASTILLO, Lisa Earl. Entre a oralidade e a escrita: a etnografia nos candomblés da Bahia. Salvador: Edufba, 2008.

-. Entre memória, mito e história: viajantes transatlãnticos da Casa Branca, in João José Reis e Elciene Azevedo (org.), Escravidão e suas sombras, Salvador, Edufba, 2012, pp. 65110.

- O terreiro do Alaketu e seus fundadores: Historia e genealogia familiar, 1807-67. AfroÁsia, no. 43 (2011), pp. 213-59.

- e Parés, Luis Nicolau. Marcelina da Silva e seu mundo: novos dados para uma historiografia do candomblé ketu. Afro-Ásia, n³6 (2007), pp. 111-151.

- e Parés, Luis Nicolau. The Elusive Limits of the Secret: Afro-Brazilian Religion in the Photography of Pierre Verger. In Alex Baradel (org.) O Brasil de Pierre Verger. Salvador: Fundação Pierre Verger, 2006, pp. 203-231.

CLOUZOT, Henri-Georges. Les Possédées de Bahia. Paris-Match, maio, n 19 (1951), pp. 12 $-18$.

DANTAS, Beatriz Góis. Vovó nagô e papai branco: usos e abusos da África no Brasil. Rio de Janeiro: Graal, 1988.

DERRIDA, Jacques. On Grammatology. Baltimore: Johns Hopkins University Press, 1976.

ERMAKOFF, George. O negro na fotografia brasileira do século XIX. Rio de Janeiro: G. Ermakoff Casa Editorial, 2004.

FOUCAULT, Michel. The Order of Things: an Archaeology of the Human Sciences. Nova York: Vintage Books, 1994 [1970].

_. Discipline and Punish. Nova York: Vintage Books, 1995 [1975].

JOHNSON, Paul. Secrets, Gossip, and Gods: The Transformation of Brazilian Candomblé. 
Nova York e Londres: Oxford University Press, 2002.

KOSSOY, Boris. Fotografia e história. São Paulo: Editorial Ateliê, 2003 (2a edição revista e ampliada).

KOUTSOKOS, Sandra Sofia Machado. Negros no estúdio do fotógrafo. Brasil, segunda metade do século XIX. Campinas, Editora Unicamp, 2010.

LEITE, Marcelo Eduardo. Typos de pretos: escravos na fotografia de Christiano Jr. Visualidades, vol.9 no.1 (jan-jun 2011), pp. 25-47.

LÉVI-STRAUSS, Claude. Tristes Tropiques. Nova York: Washington Square Press, 1977 [1955].

LANDES, Ruth. The City of Women. Albuquerque: University of New Mexico Press, 1994 [1947].

—. A cidade das mulheres. Rio de Janeiro: Editora UFRJ, 2002.

LIMA, Vivaldo da Costa. A família de santo nos candomblés jeje-nagôs da Bahia. Salvador: Corrupio, 2003.

LÜHNING, Ángela. Acabe com este santo, Pedrito vem aí: mito e realidade da perseguição policial ao candomblé baiano entre 1920 e 1942. Revista USP, n. 28, 1995, pp. 193-220.

LUZ, Marco Aurélio. Agdá: Dinâmica da civilização africano-braslieira. Salvador: Edufba, 2000.

MATORY, J. Lorand. Black Atlantic Religion: Tradition, Transnationalism and Matriarchy in the Afro-Brazilian Candomblé, Princeton: Princeton University Press, 2005.

NÓBREGA, Cida e Regina Echeverría. Mãe Menininha do Gantois: uma biografia. Salvador: Corrupio, 2006.

OLIVEIRA, Waldir Freitas e Vivaldo da Costa Lima. Cartas de Edison Carneiro a Artur Ramos. Salvador: Corrupio, 1987.

OMARI-TUNKARA, Mikelle Smith. Manipulating the Sacred: Yoruba Art, Ritual and Resistance in Brazilian Candomblé. Detriot: Wayne State University Press.

PINNEY, Christopher. The Parallel Histories of Anthropology and Photography. In Elizabeth Edwards, (org.), Anthropology and Photography, 1860-1920. New Haven e Londres: Yale University Press, 1992, pp. 74 - 95.

QUERINO, Manoel. A raça africana e seus costumes na Bahia. Salvador: Imprensa Oficial do Estado da Bahia, 1917.

REIS, João José. Domingos Sodré, um sacerdote africano: escravidão, liberdade e candomblé na Bahia do século XIX. São Paulo: Companhia das Letras, 2008.

RIO, João do. As religiões no Rio. Rio de Janeiro: José Olympio Editora, 2006 [1904].

RODRIGUES, Raimundo Nina. Os africanos no Brasil. Brasília: Editora da Universidade de Brasília, 1982 [1932].

SANTOS, Juana Elbein dos. Os nagô e a morte: padé, asese e o culto egun na Bahia. Rio de 
Janeiro: Vozes, 1984 [1975].

SCHWARCZ, Lilia Moritz. O espetáculo das raças: Cientistas, instituições e questão racial no Brasil do século XIX. São Paulo: Companhia das Letras, 1993.

SILVA, Arlindo e José Medeiros. As noivas dos deuses sanguinários. O Cruzeiro, 15/09/1951, pp. 12-24.

SODRÉ, Muniz. A verdade seduzida. Petrópolis: Vozes, 1988.

SONTAG, Susan. On Photography. Nova York: Anchor Books, 1977.

TACCA, Fernando de. Imagens do sagrado: Entre Paris-Match e O Cruzeiro. Campinas: Editora Unicamp, 2009.

—. "Candomblé: Imagens do Sagrado". Revista da Antropologia Social, edição especial da $4^{\mathrm{a}}$ Reunião de Antropologia do Mercosul (2003) pp. 147 - 164.

THOMPSON, Robert Farris. Flash of the Spirit: Afro-American Art and Philosophy. Nova York: Random House, 1983.

-. Face of the Gods: Art and Altars of Africa and the African Americas. New York: Museum for African Art, 1993.

VAN DE PORT, Mattijs. Visualizing the Sacred: Video Technology, 'Televisual' Style, and the Religious Imagination in Bahian Candomblé. American Ethnologist, vol. 33, no. 3, (2006), pp. 444 - 461.

VERGER, Pierre. Os libertos: sete caminhos na liberdade de escravos da Bahia no século XIX. Salvador: Corrupio, 1992.

—. Ewé: o uso das plantas na sociedade iorubá. São Paulo: Editora Schwarcz, 1995.

—. Orixás: Deuses africanos no Novo Mundo, Salvador, Corrupio, 1987.

—. Dieux d'Afrique. Paris: Paul Hartman, 1954.

Recebido em: 16 de novembro de 2013.

Aprovado em: 08 de dezembro de 2013. 
